\title{
EFEKTIVITAS PENGGUNAAN DIGITAL BOOK INTERACTIVE DALAM MENINGKATKAN MOTIVASI BELAJAR MAHASISWA PADA MATAKULIAH FISIOLOGI HEWAN DI PROGRAM STUDI PENDIDIKAN BIOLOGI STKIP GARUT
}

\author{
Hudiana Hernawan \\ Program Studi Pendidikan Biologi STKIP Garut
}

\begin{abstract}
Rendahnya mutu pendidikan di Indonesia salah satu penyebabnya adalah minimnya sumber bahan ajar yang dapat dimanfaatkan yang saat ini masih konvensional dan belum dapat meningkatkan minat dan motivasi mahasiswa untuk mempelajarinya. Salah satu alternatif pemecahan masalah ini adalah dengan diproduksi menjadi Digital Book Interactive. Produk ini dapat mengintegrasikan antara teknologi komputer dengan pembelajaran, tidak hanya tekstual tapi juga audiovisual. Tujuan dari penelitian ini adalah menghasilkan model Digital Book Interactive yang dapat meningkatkan motivasi belajar mahasiswa. Penelitian ini menggunakan metode kuasi eksperimen dengan desain penelitian yang digunakan adalah Non-equivalent control group pre-test and post-test design, yaitu penelitian yang dilaksanakan pada dua kelas, yaitu satu kelas eksperimen yang menggunakan bahan ajar Fisiologi Hewan dalam bentuk Digital Book Interactive dan satu kelas kontrol yang menggunakan bahan ajar Fisiologi Hewan dalam bentuk buku cetak. Instrumen angket digunakan untuk menjaring data motivasi belajar mahasiswa sebelum dan setelah mendapatkan pembelajaran. Hasil penelitian diperoleh, motivasi belajar akhir mahasiswa yang menggunakan Digital Book Interactive $(85,88)$ nyata lebih besar dibandingkan dengan mahasiswa yang menggunakan buku cetak $(69,08)$. Selanjutnya, peningkatan motivasi belajar mahasiswa yang menggunakan Digital Book Interactive $(0,7184)$ nyata lebih besar dibandingkan dengan peningkatan motivasi belajar siswa yang menggunakan buku cetak $(0,3576)$. Kesimpulan dari penelitian ini, Digital Book Interactive efektif dalam meningkatkan motivasi belajar siswa dalam matakuliah Fisiologi Hewan di Program Studi Pendidikan Biologi STKIP Garut.
\end{abstract}

Katakunci: teknologi informasi, digital book interactive, fisiologi hewan, motivasi belajar

\section{PENDAHULUAN}

Secara umum, materi kuliah Fisiologi Hewan sulit untuk dipelajari oleh mahasiswa Program Studi Pendidikan Biologi, sehingga banyak mahasiswa kurang tertarik untuk mempelajarinya dan kurang berminat untuk membaca buku atau textbook tentang Fisiologi. Hal ini disebabkan oleh beberapa aspek antara lain: kompleksitas materi kuliah Fisiologi Hewan dan buku ajar yang masih bersifat konvesional. Buku ajar yang secara umum digunakan baik oleh dosen maupun mahasiswa adalah buku ajar dalam bentuk cetak yang konvensional yang belum dapat meningkatkan minat belajar mahasiswa, dan merupakan salah satu penyebab rendahnya motivasi khususnya motivasi membaca mahasiswa. Bentuk buku ajar yang demikian biasanya menjadikan mahasiswa kurang menarik, kurang memahami, dan kurang mandiri karena masih mengandalkan penjelasan dosen. Padahal, tersedianya sumber belajar yang ekonomis, praktis dan sederhana, fleksibel, relevan, dan memiliki nilai positif akan mendukung kegiatan pembelajaran yang lebih efektif serta memudahkan mencapai tujuan pembelajaran (Rohani, 2004). Selain itu, menurut Kusuma (2011:49), belajar mandiri tidak berarti belajar sendiri. Hal yang terpenting dalam proses belajar mandiri adalah peningkatan kemauan dan keterampilan mahasiswa dalam proses belajar tanpa bantuan orang lain, sehingga mereka tidak bergantung pada dosen, teman, atau orang lain dalam belajar. Proses belajar mandiri memberi kesempatan mahasiswa untuk mencerna materi ajar dengan sedikit bantuan dosen. Mereka mengikuti kegiatan belajar dengan materi ajar yang sudah dirancang khusus sehingga masalah atau kesulitan belajar sudah diantisipasi sebelumnya.

Ketidakmandirian mahasiwa dalam melaksanakan proses pembelajaran merupakan suatu keadaan motivasi belajar mahasiswa yang rendah yang pada gilirannya akan menyebabkan rendahnya mutu pendidikan. Untuk mengatasi kendala-kendala dalam pembelajaran, khususnya dalam meningkatkan motivasi membaca mahasiswa yang masih rendah, perlu dikembangkan buku ajar yang memperhatikan gaya dan kemampuan belajar mahasiswa, mendukung 
pembelajaran perseorangan dan mandiri, serta dapat memudahkan belajar mahasiswa. Menurut Dick dan Carey (1990:72), bahan pembelajaran hendaknya merupakan bahan yang seluruhnya dapat dipelajari sendiri oleh mahasiswa. Maksudnya, bahan tersebut dapat memberikan kesempatan pada mahasiswa untuk mempelajarinya tanpa bergantung pada penjelasan dosen. Pembelajaran yang baik juga akan mengaktifkan mahasiswa dalam memberikan tanggapan, umpan balik, dan juga mendorong mahasiswa untuk melakukan praktikpraktik dengan benar. Dengan demikian, mengemas bahan ajar secara tersusun dan berkualitas sangat penting dalam meningkatkan kualitas proses pembelajaran. Oleh karena itu, bahan ajar merupakan unsur yang menentukan keberhasilan mahasiswa belajar.

Salah satu alternatif pemecahan masalah di atas, yaitu dengan memanfaatkan kemajuan Teknologi Informasi. Produk Teknologi Informasi yang dapat dijadikan media pelengkap dan sarana belajar adalah Digital Book Interactive yang merupakan multimedia yang berisikan informasi digital yang berwujud teks atau gambar yang merupakan representasi elektronik dari sebuah buku berbentuk digital (Lee, 2004 dalam Darmawan, 2011) yang dapat memfasilitasi kebutuhan peserta didik, tidak hanya tekstual tetapi juga audio dan visual (Munir, 2010).

Penelitian ini merupakan penelitian terapan, artinya dalam penelitian diujicobakan penerapan atau penggunaan bahan perkuliahan dalam bentuk Digital Book Interactive agar mahasiswa memiliki motivasi untuk membaca dan mempelajari dengan baik, di samping itu juga untuk melatih mahasiswa belajar secara mandiri. Mahasiswa tidak hanya menjadi penerima yang pasif melainkan juga menjadi penentu pembelajaran bagi dirinya sendiri. Pembelajaran yang demikian diharapkan akan memberikan motivasi yang lebih tinggi karena Digital Book Interactive selalu dikaitkan dengan kesenangan dan kreativitas. Melalui model bahan ajar yang bersifat interaktif akan membuat mahasiswa belajar tanpa beban dan tanpa tekanan karena beragamnya penyajian materi yang menyenangkan sehingga mahasiswa termotivasi belajar dengan cepat.

Tujuan penelitian ini adalah menghasilkan Digital Book Interactive yang dapat meningkatkan motivasi belajar mahasiswa pada matakuliah Fisiologi Hewan di Program Studi Pendidikan Biologi. Adapun manfaat dari hasil penelitian ini adalah dengan menggunakan Digital Book Interactive yang bersifat multimedia dalam proses pembelajaran akan memberikan pengalaman belajar yang bervariasi sehingga merangsang minat mahasiswa untuk belajar; menciptakan situasi belajar yang efektif; dan memberikan motivasi belajar kepada peserta didik (Wiryokusumo, 2002).

Pengembangan dan penerapan model Digital Book Interactive ini penting dilakukan karena beberapa hal berikut. Pertama, ada perubahan budaya belajar mahasiswa dari yang klasikal ke mandiri. Kedua, dapat mengatasi kekurangan bahan dan rujukan bahan ajar sehingga dengan mudah dapat dipahami oleh para mahasiswa. Ketiga, dapat mengatasi kekurangan sumber pembelajaran yang dirancang secara sistematis dengan berpegang pada prinsip-prinsip pengembangan pembelajaran. Keempat, materi pembelajaran berbentuk elektronik akan memudahkan mahasiswa dalam proses pembelajaran karena bahan yang dikembangkan tersebut sudah merupakan bahan yang siap pakai. Kelima, berperan dalam mengembangkan diri mahasiswa, terutama untuk mengembangkan potensi dan kemandiriannya. Para mahasiswa dapat mengikuti program pembelajaran sesuai dengan kecepatan dan kemampuan sendiri, lebih banyak belajar mandiri, dan dapat menekankan penguasaan bahan pelajaran secara optimal. Keenam, belajar dalam bentuk Digital Book Interactive merupakan bentuk belajar yang efektif dan efisien di zaman sekarang ini, karena harga kertas melambung tinggi dan banyak kemungkinan cepat rusak.

\section{HASIL PENELITIAN}

A. Deskripsi Motivasi Siswa Kelas Kontrol dan Kelas Eksperimen

Deskripsi data berupa nilai rata-rata (mean), simpangan baku, nilai minimum, dan nilai maksimum dari hasil pengolahan data disajikan pada tabel di bawah ini.

\section{Tabel 2 \\ Deskripsi Motivasi Belajar Kelas Kontrol dan Kelas Eksperimen}

\begin{tabular}{|c|c|c|c|c|c|c|}
\hline \multicolumn{7}{|c|}{ Statistics } \\
\hline & $\begin{array}{l}\text { Motivasi Awal } \\
\text { Kelas Kontrol }\end{array}$ & $\begin{array}{l}\text { Motivasi Akhir } \\
\text { Kelas Kontrol }\end{array}$ & $\begin{array}{c}\text { Peningkatan } \\
\text { Motivasi Kelas } \\
\text { Kontrol }\end{array}$ & $\begin{array}{l}\text { Motivasi Awal Kelas } \\
\text { Eksperimen }\end{array}$ & $\begin{array}{l}\text { Motivasi Akhir Kelas } \\
\text { Eksperimen }\end{array}$ & \begin{tabular}{|c|} 
Peningkatan \\
Motivasi Kelas \\
Eksperimen
\end{tabular} \\
\hline $\begin{array}{l}\text { Mean } \\
\text { Median }\end{array}$ & $\begin{array}{l}50.72 \\
50.00\end{array}$ & $\begin{array}{l}69.08 \\
68.00\end{array}$ & $\begin{array}{r}.3576 \\
.3400\end{array}$ & $\begin{array}{r}51.16 \\
53.00\end{array}$ & $\begin{array}{r}85.88 \\
89.00\end{array}$ & $\begin{array}{r}.7184 \\
.7600\end{array}$ \\
\hline Std. Deviation & 7.514 & 4.434 & .13004 & 7.016 & 8.521 & .15334 \\
\hline Minimum & 35 & 58 & .19 & 38 & 71 & .43 \\
\hline Maximum & 63 & 82 & .68 & 62 & 98 & 96 \\
\hline
\end{tabular}

Dari tabel di atas diketahui bahwa rata-rata/mean motivasi belajar sebelum dilakukan penelitian pada kelas kontrol sebesar 50,72 dengan nilai terkecilnya 35 dan terbesarnya 63, serta simpangan baku sebesar 7.514. Setelah pembelajaran dengan memanfaatkan buku cetak rata-rata motivasi mengalami kenaikkan menjadi 69,08 dengan nilai terkecilnya 58 dan terbesarnya 82 , serta simpangan baku sebesar 4,434. Dari hal tersebut diketahui terjadi peningkatan motivasi belajar (gain) sebesar 0,3576 dengan skor peningkatan terkecilnya 0,19 dan terbesarnya 0,68, serta simpangan baku sebesar 0,13. Merujuk pada interpretasi gain, peningkatan motivasi belajar pada kelas kontrol tersebut termasuk dalam kategori sedang.

Selanjutnya, dari tabel di atas diketahui pula bahwa ratarata/mean motivasi belajar sebelum dilakukan penelitian pada kelas eksperimen sebesar 51,16 dengan nilai terkecilnya 38 dan terbesarnya 62, serta simpangan baku sebesar 7.016. Setelah pembelajaran dengan memanfaatkan Digital Book Interactive rata-rata motivasi mengalami kenaikkan menjadi 85,88 dengan nilai terkecilnya 71 dan terbesarnya 98 , serta simpangan baku sebesar 8,521. Dari hal tersebut diketahui terjadi peningkatan motivasi belajar (gain) sebesar 0,7184 dengan skor peningkatan terkecilnya 0,43 dan terbesarnya 0,96 , serta simpangan baku 
sebesar 0,1533 . Merujuk pada interpretasi gain, peningkatan motivasi belajar pada kelas kontrol tersebut termasuk dalam kategori tinggi.

B. Efektivitas Penggunaan Digital Book Interactive dalam Meningkatkan Motivasi Belajar

Hasil pengujian statistik untuk data awal, akhir, dan peningkatan motivasi belajar mahasiswa dapat dilihat pada tabel di bawah ini.

Tabel 3

Uji Perbedaan Motivasi Belajar Mahasiswa Kelas Kontrol

dengan Kelas Ekperimen

\begin{tabular}{|l|l|l|}
\hline Uji Perbedaan & $\begin{array}{l}\text { Hasil Uji } \\
\text { Statistik }\end{array}$ & $\begin{array}{l}\text { Uji yang } \\
\text { digunakan }\end{array}$ \\
\hline Motivasi Awal & 0,831 & $\begin{array}{l}\text { Independent } \\
\text { Samples Test }\end{array}$ \\
\hline Motivasi Akhir & $0,000^{*}$ & Mann-Whitney U \\
\hline $\begin{array}{l}\text { Peningkatan } \\
\text { Motivasi }\end{array}$ & $0,000^{*}$ & $\begin{array}{l}\text { Independent } \\
\text { Samples Test }\end{array}$ \\
\hline
\end{tabular}

Keterangan: * terdapat perbedaan

Dari tabel di atas, menunjukkan tidak ada perbedaan motivasi belajar awal mahasiswa, yang dapat dilihat dari nilai Sig. (2-tailed) sebesar 0.831 yang lebih besar dari nilai $\alpha$ yang ditetapkan $(0,05)$. Selanjutnya, terdapat perbedaan motivasi belajar akhir dan peningkatan motivasi belajar, yang dapat dilihat dari nilai Sig. (2-tailed) sebesar 0,000 yang lebih kecil dari nilai $\alpha$ yang ditetapkan $(0,05)$. Dengan kata lain, tidak terdapat perbedaan motivasi belajar awal mahasiswa, selanjutnya terdapat perbedaan motivasi belajar akhir dan peningkatan motivasi belajar antara mahasiswa yang menggunakan Digital Book Interactive dengan mahasiswa yang menggunakan buku cetak.

Kesimpulan dari hasil penelitian di atas, motivasi belajar akhir mahasiswa yang menggunakan Digital Book Interactive $(85,88)$ nyata lebih besar dibandingkan dengan mahasiswa yang menggunakan buku cetak $(69,08)$. Selanjutnya, peningkatan motivasi belajar mahasiswa yang menggunakan Digital Book Interactive $(0,7184)$ nyata lebih besar dibandingkan dengan peningkatan motivasi belajar siswa yang menggunakan buku cetak $(0,3576)$. Dengan kata lain, Digital Book Interactive efektif dalam meningkatkan motivasi belajar siswa dalam matakuliah Fisiologi Hewan di Program Studi Pendidikan Biologi STKIP Garut.

\section{PEMBAHASAN}

Berdasarkan hasil uji perbedaan dua rata-rata, motivasi awal kedua kelas adalah sama namun setelah dilakukan penelitian dengan menggunakan buku cetak untuk kelas kontrol dan Digital Book Interactive untuk kelas eksperimen dalam pembelajarannya terjadi perbedaan motivasi belajar akhir dan peningkatan motivasi belajar. Motivasi belajar akhir mahasiswa yang menggunakan Digital Book Interactive $(85,88)$ nyata lebih besar dibandingkan dengan mahasiswa yang menggunakan buku cetak $(69,08)$. Selanjutnya, peningkatan motivasi belajar mahasiswa yang menggunakan Digital Book Interactive $(0,7184)$ nyata lebih besar dibandingkan dengan peningkatan motivasi belajar siswa yang menggunakan buku cetak $(0,3576)$. Dengan kata lain, Digital Book Interactive efektif dalam meningkatkan motivasi belajar siswa dalam matakuliah Fisiologi Hewan di Program Studi Pendidikan Biologi STKIP Garut.

Seperti diketahui, motivasi berasal dari kata motif yang berarti dorongan atau alasan. Motif merupakan tenaga pendorong yang mendorong manusia untuk bertindak atau suatu tenaga di dalam diri manusia, yang menyebabkan manusia bertindak atau melakukan sesuatu. Dengan kata lain, motivasi merupakan tenaga pendorong yang mendorong manusia untuk bertindak atau melakukan sesuatu. Sedangkan motivasi belajar itu sendiri adalah keseluruhan daya penggerak psikis di dalam diri seseorang yang menimbulkan kegiatan belajar, menjamin kelangsungan kegiatan belajar dan memberikan arah pada kegiatan belajar itu demi mencapai suatu tujuan (Sardiman, 2010).

Motivasi memiliki 3 komponen, salah satunya adalah komponen tujuan. Adapun komponen tujuan itu sendiri adalah hal yang ingin dicapai oleh individu. Siswa yang mempunyai tujuan tertentu dalam melakukan suatu pekerjaan, maka ia akan melakukan pekerjaan tersebut dengan penuh semangat (Sardiman, 2010). Kondisi tersebut, terjadi pada siswa di kelas eksperimen, yang mana skor motivasinya lebih tinggi dibandingkan dengan siswa di kelas kontrol. Salah satu faktor yang menyebabkan tingginya motivasi di kelas eksperimen adalah digunakannya Digital Book Interactive. Dalam hal ini, Digital Book Interactive dianggap sebagai faktor luar yang mampu mempengaruhi motivasi siswa. Sesuai dengan pendapat Sardiman (2005:189) yang menyatakan bahwa motivasi ekstrinsik adalah motif-motif yang aktif dan berfungsinya karena adanya perangsang dari luar. Sejalan dengan itu pula, Suryabrata (1994:72) menyatakan motivasi ekstrinsik, yaitu motivasi yang berfungsi karena adanya rangsangan dari luar.

Terjadinya peningkatan motivasi belajar pada kelas eksperimen selain karena penggunaan media Digital Book Interactive, juga dapat mengakomodir berbagai macam gaya belajar mahasiswa. Digital Book Interactive yang diterapkan menggunakan berbagai macam media, seperti tulisan, audio, dan visual yang memberi suasana yang menarik, dinamis dan siswa tampak menikmati pembelajaran sehingga mahasiswa terlihat antusias dalam kegiatan pembelajaran. Hal ini selaras dengan pendapat Islam dkk (2014) dalam jurnal penelitiannya yang berjudul Child Education Through Animation: An Experimental 
Study menyatakan bahwa pendidik dalam mengajar peserta didik mereka dengan memanfaatkan buku teks bersama dengan instruksi lisan, metode pengajaran dan pembelajaran ini dapat diubah dengan mengembangkan Teknologi Informasi dan Komunikasi (TIK). Oleh karena itu, menurut peneliti sudah waktunya peserta didik untuk beradaptasi dengan pembelajaran yang interaktif. Hal ini sangat diperlukan untuk menciptakan pembelajaran yang berkualitas tinggi dan realistis bagi peserta didik. Integrasi materi pembelajaran secara visual dapat meningkatkan respon dan persepsi peserta didik terhadap pendekatan pembelajaran ini. Pendekatan pembelajaran yang dikemas dalam penelitian ini mungkin metode yang tepat terutama untuk peserta didik di lingkungan pendidikan.

Motivasi dapat menentukan tingkat berhasil atau gagalnya perbuatan belajar peserta didik. Pembelajaran yang bermotivasi pada hakekatnya adalah pembelajaran yang disesuaikan dengan kebutuhan, dorongan, motif, minat yang ada pada peserta didik. Selanjutnya, Surya (2014:12) menyatakan bahwa pandangan psikologi kognitif menekankan bahwa pembelajaran bukan hanya kognisi semata-mata, melainkan juga aspek motivasional dan sistem keyakinan pembelajaran. Motivasi mahasiswa dan derajat keyakinan mahasiswa dalam proses pembelajaran merupakan faktor penting dalam pembelajaran. Oleh karena itu, sangat penting untuk menumbuhkan motivasi mahasiswa membangun keyakinan diri mereka sendiri dalam proses pembelajaran.

Terjadinya peningkatan motivasi pada kelas yang menggunakan Digital Book Interactive merupakan modal bagi mahasiswa tersebut untuk lebih maju, hal ini sesuai dengan pendapat Sardiman (2014:85) yang menyatakan motivasi dalam belajar memiliki fungsi diantaranya: 1) mendorong manusia untuk berbuat, artinya merupakan motor penggerak dari setiap kegiatan yang akan dikerjakan; 2) menentukan arah perbuatan, artinya dapat memberikan arah yang harus dikerjakan sesuai dengan rumusan tujuan yang telah ditetapkan; 3) menyeleksi perbuatan, yakni memilih kegiatan yang dapat mendukung untuk mencapai tujuan serta menyisihkan kegiatan atau perbuatan-perbuatan yang tidak sesuai dengan tujuan; dan 4) mendorong usaha dalam mencapai prestasi, seorang mahasiswa yang memiliki motivasi yang kuat akan lebih rajin belajarnya sehingga hasil belajarnya pun akan lebih baik. Di dalam kegiatan belajar mengajar peranan motivasi sangat diperlukan, dengan motivasi yang baik mahasiswa dapat mengembangkan aktivitas dan inisiatif serta dapat mengarahkan dan memelihara ketekunan dalam melakukan kegiatan belajar.

\section{SIMPULAN DAN REKOMENDASI}

Hasil observasi menunjukkan, mahasiswa lebih menyenangi perkuliahan yang banyak melibatkan dirinya dalam pembelajaran sehingga perlu dikembangkan bahan pembelajaran yang interaktif. Dengan menggunakan bahan ajar yang bersifat interaktif, mahasiswa sangat senang, mudah memahami, dan mudah mengoperasikannya, kondisi ini menyebabkan motivasi belajar mahasiswa menjadi meningkat.
Oleh karena itu, penggunaan Digital Book Interactive efektif dalam meningkatkan motivasi belajar mahasiswa pada matakuliah Fisiologi Hewan di Program Studi Pendidikan Biologi STKIP Garut.

Peneliti merekomendasikan untuk dijadikan bahan pertimbangan dan pemikiran, bahwa aplikasi Digital Book Interactive merupakan salah satu alternatif media pembelajaran interaktif yang dapat mengembangkan sikap aktif dan mandiri, maka sebaiknya aplikasi Digital Book Interactive dapat digunakan untuk setiap materi pada matakuliah lainnya sebagai solusi inovatif untuk mengatasi permasalahan dan kesulitan mahasiswa dalam proses pembelajaran.

\section{DAFTAR PUSTAKA}

Buzzetto, et.al., (2007). Reading in A Digital Age: e-Books Are Students Ready For This Learning Object?. Interdisciplinary Journal of Knowledge and Learning Objects Volume 3. Editor: Alex Koohang

Darmawan, Deni (2011). Teknologi Pembelajaran. Bandung : Remaja Rosdakarya

Dick, W and Carey, L (1990). The Systematic Design of Instruction. Glenview, Illinois London, England: Scat, Foresman \& Company.

Islam, dkk. (2014). Child Education Through Animation: An Experimental Study. International Journal of Computer Graphics \& Animation (IJCGA) Vol.4, No.4, October 2014.

Kusuma, A (2011). "E-Learning dalam Pembelajaran Bahasa". Lentera Pendidikan, Vol. 14, Nomor 1, 2011.

Munir (2010). Kurikulum Berbasis Teknologi Informasi. Bandung: PT. Alfabeta.

Rohani, Ahmad (2004). Pengelolaan Pengajaran. Jakarta : PT Rineka Cipta

Sardiman. A.M. (2005). Interaksi Dan Motivasi Belajar Mengajar. Jakarta: Rajawali Pres

(2010). Interaksi dan Motivasi Belajar Mengajar. Jakarta: Rajawali Press

(2014). Interaksi dan Motifasi Belajar Mengajar. Jakarta: Rajawali Pers

Suryabrata , S. (1994). Metodologi Penelitian. PT RajaGrafindo Persada : Jakarta

Surya, M. (2014). Strategi Kognitif. Garut: STKIP Press.

Wiryokusumo, Iskandar (2002). Pengantar Teknologi Pendidikan. Matrikulasi Program Pascasarjana Teknologi Pembelajaran Universitas PGRI Adibuana Surabaya. Bahan Matrikulasi tidak diterbitkan. Surabaya: Program Pascasarjana Teknologi Pembelajaran Universitas PGRI Surabaya 